\title{
ROSA LUXEMBURG
}

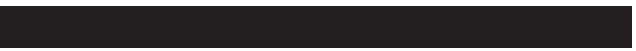

Teppo Eskelinen: Sorron rajat. Rosa Luxemburg poliittisen liikkeen, talouden ja siirtomaavallan teoreetikkona. Tutkijaliitto. Helsinki 2015

Teppo Eskelisen Rosa Luxemburgia poliittista ajattelua käsittelevä kirja on mieluisa yllätys. Tuntuu hyvältä, että "nuoremman polven" tutkija on kiinnostunut tästä erikoisesta ja omaperäisestä naisesta, jota voidaan hyvällä syyllä pitää yhtenä viime vuosisadan merkittävimmistä eurooppalaisista poliittisista ajattelijoista ja vaikuttajista. Toisen internationaalin marxilaisten teoreetikkojen tutkiminen ei ole ollut reaalisosialismin romahtamisen jälkeen kovin muodikasta, vaikka viime vuosina on ollut havaittavissa kiinnostuksen heräämistä uudelleen. Talouden globalisaation edetessä onkin ollut jo jonkin aikaa aavistettavissa, että tutkijat kiinnostuvat uudelleen toisen internationaalin teoreetikoista, jotka pohtivat kapitalismin laajenemisen dynamiikkaa ja laajentumisen teoreettisia ja historialisia rajoja. Eskelisen kirjaa voidaan pitää yhtenä osoituksena tästä uudelleen virinneestä kiinnostuksesta aiheeseen.

Eskelisen kirjaa on siinäkin suhteessa tervehdittävä ilolla, että Luxemburg on jostain syystä jäänyt nimenomaan Suomessa vähälle huomiolle. Olen tuskin väärässä väittäessäni, että Luxemburgia ei tunnettu sen enempää vanhassa yhtenäisessä työväenpuolueessa kuin sen kahdessa perillisessä, sosiaalidemokraattisessa ja kommunistisessa puolueessa. Ja vaikka Tommy Tabermann otsikoi esikoisrunoteoksensa Ruusuja Rosa Luxemburgille, niin uskallan väittää, ettei suomalainen uusvasemmisto 1960-luvulla Rosa Luxemburgin henkilöä ja ajattelua kovin syvällisesti tuntenut. Sanottu pätee myös Rosa Luxemburgia koskevaan akateemiseen tutkimukseen Suomessa: se al- koi vasta Matti Viikarin kirjoittamista jälkisanoista Luxemburgin teokseen Sosialidemokratian kriisi (Helsinki 1973). Ero tässä suhteessa esimerkiksi Saksaan on huomattava. Suomalaisesta näkökulmasta hämmentävältä saattaa tuntua, että Karl Dietz -kustantamo julkaisi hiljattain Luxemburgin kasvikokoelman: "Herbarium" von Rosa Luxemburg (Berlin 2016).

Kirjan takakannen mukaan Sorron rajat "on ensimmäinen laaja suomenkielinen Rosa Luxemburgin teorioiden esittely ja arvio nykyajan talousjärjestelmän ja politiikan näkökulmasta."Toteamus pitää paikkansa vain lauseen loppuosan osalta. Kuten Juha Drufva Kansan Uutisiin (KU 9.9.2016) kirjoittamassaan kirja-arviossa toteaa, muun muassa SKDL:n kansanedustajana toiminut Mirjam VireTuominen julkaisi jo vuonna 1995 teoksensa Kuka oli Rosa Luxemburg. Vaikka teos ei ehkä täytä tieteellisen tutkimuksen vaatimuksia, on se silti oiva johdanto Luxemburgin elämään ja ajatteluun. Myös Matti Viikarin jälkisanat hänen kääntämäänsä edellä mainittuun Luxemburgin teokseen Sosialidemokratian kriisi (1973) on syytä muistaa. Myös allekirjoittanut on kirjoittanut Historialliseen Aikakauskirjaan Luxemburgin poliittisesta urasta, ajattelusta, Luxemburg-tutkimuksen teemoista ja sen lähdepohjasta laajan artikkelin: Puolalainen, juutalainen, vallankumouksellinen nainen: Rosa Luxemburg (Haik/2 1999).

Kaikista Eskelisen kirjassa esiin nostamista teemoista on runsaasti aikaisempaa tutkimuskirjallisuutta, jo lähtien vuonna 1929 ilmestyneestä Luise Kautskyn ystävästään kirjoittamasta elämäkerrasta Rosa Luxemburg. Ein Gedengenbuch (Berlin 1929). Luxemburg-tutkimuksen keskeisiä teemoja ovat olleet Eskelisenkin käsittelemät tai sivuamat kysymykset: Luxemburg ihmisenä, sosiaalireformien ja val- 
lankumouksen suhde, yleislakko poliittisena aseena, massojen ja puolueen suhde, kapitalismin romahtaminen ja kansakunnan oikeus järjestäytyä valtioksi.

Eskelisen Luxemburgia käsittelevä kirja jakaantuu yhdeksään päälukuun ja sivumäärällä mitattuna pääosan siitä vie kirjan viisi viimeistä lukua, joissa Eskelinen käsittelee Luxemburgin vuonna 1913 ilmestynyttä teosta Die Akkumalation des Kapitals ja tämän teoksen soveltuvuutta nykytalouden ilmiöiden selittämiseen. Kirjan alkupään luvuissa Eskelinen käsittelee johdannon ohella suppeasti Luxemburgin henkilöhistoriaa sekä tämän kahta Die Akkumalation des Kapitals -kirjaa edeltänyttä kiistakirjoitusta Sozialreform oder Revolution ja Massenstreik, Partei und Gewerkschaften, jonka merkitystä tämän päivän kansalaisliikkeille Eskelinen kirjan yhteenvetoluvussa myös käsittelee. Kirjan painopisteet näkyvät myös kirjan nimessä: Sorron rajat viittaa Luxemburgin teokseen Die Akkumalation des Kapitals ja otsikon selitysosa tämän teokseen Massenstreik, Partei und Gerwerkschaften.

Eskelinen kutsuu Die Akkumalation des Kapitals -teosta Luxemburgin teoreettiseksi päätyöksi. Näin voi tietenkin tehdä ja niin ovat tehneet myös eräät Luxemburg-tutkijat ennen häntä. Toisaalta voi kysyä, miksi kyseinen teos olisi merkittävämpi kuin jokin muu Luxemburgin kirjoittama teos. Olisi ehkä parempi puhua vaatimattomammin hänen yhdestä päätyöstään tai rajata ilmaisu koskemaan Luxemburgin taloudellista ajattelua.

Luxemburg oli Saksan sosiaalidemokraattisessa puolueessa ilmiö, eräänlainen sensaatio, joka tietoisesti pyrki puheillaan ja kirjoituksillaan antamaan puolueen toiminnan suunnan tässä useinkaan onnistumatta. Jokainen teoreettinen työ tai poliittinen aloite tähtäsi eteenpäin. Tästä syystä yhden yksittäisen työn nostaminen muiden yläpuolelle ei ehkä tee oikeutta Luxemburgin persoonalle ja toiminnalle.

Die Akkumalation des Kapitals -teoksen nostaminen Luxemburgin pääteokseksi on hämmentävää myös siksi, että kaikista Luxemburgin kirjoittamista kiistakirjoituksista juuri se herätti eniten vastustusta marxilaisten teoreetikkojen keskuudessa. Tämän Eskelinen toki mainitsee, ja hän myös jossain määrin referoi aikalaisten vastaväitteitä, mutta tästä huolimatta lukija olisi toivonut, että esitetty kritiikki olisi kirjassa huomioitu paremmin. Samalla olisi tullut perustelluksi se, miksi Eskelinen ohittaa esitetyn kritiikin ja nostaa Luxemburgin muiden toisen internationaalin marxilaisten yläpuolelle.

Eskelisen ongelma on ollut sama kuin yleensä Luxemburg-tutkijoiden: kun keskitytään tutkimaan pelkästään Luxemburgin ajattelua ja toimintaa, samalla peittyy näköpiiristä niiden laajempi aikakauden aatteellinen ja yhteiskunnallinen konteksti. Luxemburgin imperialismia koskeva pohdinta oli luonnollisesti osa laajempaa kapitalismin romahtamista koskevaa keskustelua. Eskelinen kyllä viittaa tähän, mutta ei esimerkiksi kerro, mitä mieltä aikaisempi tutkimus on ollut Luxemburgin marxismi-tulkinnasta ja sen yhteydestä tähän romahdusteoreettiseen keskusteluun. Luxemburgin yleislakkoa, tai massalakkoa kuten Eskelinen sitä nimittää, koskevat käsitykset ovat taas tiiviisti yhteydessä Saksan keisarikunnan poliittisiin rakenteisiin ja jatkumoihin. Sosialismin rakentamisen aloittamisesta siinä ei ollut kysymys, vaan demokraattisen Saksan rakentamisesta. Vasta ensimmäinen maailmansota ja sen barbaria nosti sosialismin aloittamisen ajankohtaiseksi.

Myös eräät Eskelisen Marx-tulkinnat herättävät ihmetystä. Bernsteinin ja muiden revisionistien tavoin hän esimerkiksi väittää Marxin kannattaneet romahdusteoriaa, siis kapitalismin romahtamista taloudellisten ristiriitojensa seurauksena sekä uskoneen niin sanottuun (absoluuttiseen) kurjistumisteoriaa eli siihen, että työläisten taloudellista asemaa ei voida kapitalismissa parantaa. On hyödytöntä kiistellä reaalisosialismin romahtamisen jälkeen Marxin opin oikeasta tulkinnasta, mutta on kuitenkin hyvä tietää, että Bernstein-debatin aikana orto- 
doksimarxilaiset kiistivät molemmat Eskelisen esittämät tulkinnat. Voi tietenkin olla, että olen ymmärtänyt Eskelisen ajatuksen väärin.

Die Akkumalation des Kapitals -teoksen ohella Eskelinen käyttää kirjassaan Luxemburgin postuumisti julkaistua vastinetta arvostelijoilleen Die Akkumulation des Kapitals oder Was die Epigonen aus der Marxschen Theorie gemacht haben. Eine Antikritik (1921). Sen sijaan kummankin kirjan varsinaista esityötä, kesken jäänyttä, Luxemburgin kuoleman jälkeen julkaistua teosta, Einfübrung in die Nationalekonomie (1925), hän ei kirjassaan käytä.

Eskelinen korostaa kirjassaan sekä Luxemburgin imperialismi-analyysin käänteentekevyyttä että sen soveltuvuutta myös nykyilmiöiden selittämiseen. Luxemburgin mielestä imperialismi oli seurausta alikulutuksesta: kasvanut tuotanto kapitalismin ydinalueilla pakotti sen laajentumaan ei-kapitalistisille alueille. Kun tuotantosuhteet olivat muuttuneet koko maailmassa kapitalistisiksi, oli se saavuttanut historialliset rajansa ja sivilisaation romahtamisen eli Luxemburgin kielenkäytössä barbarian välttämiseksi oli siirtyminen sosialismiin tullut välttämättömäksi. Luxemburg uskoi kehittäneensä Marxin Pääomassa esittämää analyysia kapitalismin uusintamisesta eteenpäin ja samalla antaneensa teoreettisen pohjan Saksan sosiaalidemokraattisen puolueen imperialismin vastaiselle politiikalle.

Eskelisen mukaan Luxemburgin teoriaa kapitalismin laajentumisen syistä voidaan soveltaa nykykapitalismin ilmiöiden tutkimiseen: esimerkiksi talouden globalisoitumisen, yksityistämisen tai vaikka maailmankaupan rakenteiden tutkimiseen. Toisaalta Eskelinen toteaa aivan oikein, että luontoa tai naisen asemaa koskeviin kysymyksiin Luxemburgin tuotannosta ei löydy vastausta. Lähtökohta on luonnollinen ja ymmärrettävä, mutta myös jossain määrin ongelmallinen. Voisi ajatella, että Luxemburg on kyllin kiinnostava henkilö omana itsenään ja oman aikansa edustajana; ilman sormella osoitettua kytkentää nykyisyyteen ja sen ongelmiin.
Eskelisen kirja on erittäin informatiivinen ja hyvin kirjoitettu, vaikka se on valmistunut, kuten tekijä kiitoksissaan toteaa, osittain työn ohessa ja suhteellisen lyhyen kirjoitusrupeaman tuloksena. Jokainen joka on lukenut Luxemburgin tekstejä ja erityisesti teosta Die Akkumalation des Kapitals osaa arvostaa Eskelisen selkeää ja vaivattomalta tuntuvaa tulkintaa $\mathrm{Lu}^{-}$ xemburgin ajattelusta. Myös Eskelisen yritys ajankohtaistaa Luxemburgin ajattelua ansaitsee tunnustuksen, kuten myös hänen pyrkimyksensä laittaa Luxemburg ja uusklassinen taloustiede keskustelemaan keskenään. Näiltä osin ei voi kuin suositella Eskelisen kirjaa niille, jotka haluavat tutustua Luxemburgin ajatteluun. Toivottavasti kirja löytää yliopistoissa tiensä eri oppiaineiden kurssivaatimuksiin.

Kirja herättää lukijassaan myös vastaväitteitä, kuten hyvän kirjan tulee tehdäkin.

Osoituksena yleisemmästä akateemisen kielitaidon yksipuolistumisesta voidaan pitää sitä, että Eskelisen käyttää tutkimuksessaan vain englanninkielisiä lähteitä. Alkuperäislähteiden eli Luxemburgin tekstien osalta tästä tuskin on haittaa tutkimukselle. Eskelinen tukeutuu työssään Helen C. Scottin ja Paul Le Blancin toimittamaan englanninkieliseen $\mathrm{Lu}^{-}$ xemburgin koottujen kirjoitusten laitokseen Socialism or barbarism. The selected writings of Rosa Luxemburg, jonka käännösten laadukkuutta on turha epäillä, jos kohta käännöksessä aina häviääkin jotain alkutekstin kontekstista ja intertekstuaalisuudesta.

Primaarilähteiden englanninkielisyyttä huomattavasti suurempi ongelma on se, että Eskelinen tukeutuu kirjassaan pelkästään englanninkieliseen toista internationaalia ja Luxemburgia käsittelevään tutkimukseen, kun suurin osa siitä on kirjoitettu saksan kielellä. Toisin sanoen Eskelisen kirja ei keskustele (riittävästi) aikaisemman toista internationaalia ja Luxemburgia koskevan tutkimuksen kanssa. Eskelisen lähdeluettelosta puuttuvat esimerkiksi Annelies Laschitzan Im Lebensrauch trotz alledem. Rosa Luxemburg. Eine Biograbie ja Rudolf Waltherin "... aber nach der Sündflut kommen wir und 
nur wir". "Zusammenbruchsteorie", Marxismus und politisches Defizit in der SPD, 1890-1914. Edellinen on johtavan Luxemburg-tutkijan kattava esitys sekä Luxemburgin henkilöstä että ajattelusta ja jälkimmäinen uraauurtava teos romahdusteoriasta Saksan sosiaalidemokraattisessa puolueessa.

Yksittäisten teosten esiin nostaminen voi tuntua epäreilulta ja epäolennaisesta, mutta laajempi tutkimuskirjallisuuden hyödyntäminen olisi syventänyt Eskelisen kirjassaan esittämää kuvaa päähenkilöstään ja tämän ajattelusta: esimerkiksi kuvaa Luxemburgin sosiaalisesta marginaalisuudesta tai tämän romahdusteoreettisesta ajattelusta. Voidaan nimittäin väittää, että syrjinnästä huolimatta Luxemburg oli monella tapaa etuoikeutettu ja hänen kapitalismin rajoja koskeva pohdintansa ei ollut niin omaperäinen kuin Eskelinen sen esittää olevan.

Harmittavinta ja ärsyttävintä Eskelisen kirjassa on se, ettei hän lainkaan näytä tuntevan aikaisempaa suomalaista aihetta koskevaa akateemista tutkimusta. Tampereen yliopiston historiatieteen laitoksella on vuodesta 1986 lähtien valmistunet neljä Eskelisen aiheen kannalta merkittävää väitöskirjaa: Markku Hyrkkäsen Sozialistische Kolonialpolitiks. Eduard Bernsteins Stellung zur Kolonialpolitik und zum Imperialismus 1882-1914, Veli-Matti Raution Die Bernstein-Debatte. Die politischeideologische Strömungen und die Parteiideologie in der Sozialdemokratische Partei Deutschlands 1898-1913, Virve Mannisen Sozialismus oder Barbarei? Der Revoluzionäre Sozialismus von Rosa Luxembug 1899-1919 ja Juha Hannikaisen Kobti modernia politiikkaa Itävallassa. Otto Baurin parlamenttistrategia 1907-1923. Lisäksi Eskelisen lähdeluettelosta puuttuu Jukka Gronowin väitöskirja On the Formation of Marxism: Karl Kautsky's Theory of Capitalism, the Marxism of the Second International and Karl Marx's Critique of Political Economy. Jos Eskelisen saksankielen taitamattomuus on ollut syynä saksan kielellä julkaistujen väitös- kirjojen ohittamiseen, niin tämä ei ole riittävä syy, koska kaikista niistä on olemassa myös suomenkieliset lisensiaattityöt.

Tässä ei ole kysymys lähdepuritanismista: ilkeämielisestä halusta huomauttaa kirjoittajaa siitä, että häneltä on jäänyt tämä tai tuo tutkimus lukematta. Eskelinen käsittelee kirjassaan edellä mainittujen teemojen lisäksi esimerkiksi sosialistista siirtomaapolitiikkaa, Bernstein-debattia, Saksan sosiaalidemokraattisen puolueen politiikka-käsitystä ja niin edelleen, lyhyesti sanottuna kaikkia niitä teemoja, joita edellä mainituissa tutkimuksissa on käsitelty. Niihin tutustuminen olisi helpottanut Eskelisen työsarkaa ja rikastuttanut hänen Luxemburg-tulkintojaan. Tutkijan etiikkaan kuuluu myös se, että aikaisemmin saman aihepiiriin kanssa uurastaneiden työ huomioidaan ja mainitaan omassa työssä. Osasyyn tapahtuneesta kantavat tietenkin myös Tutkijaliiton anonyymit arvostelijat, joiden olisi pitänyt asiasta Eskeliselle kertoa.

Kysymyksessä saattaa olla tietenkin historiatieteen ja yhteiskuntatutkimuksen ohipuhuminen. Tutkitaan samaa aihetta toisistaan tietämättä. Risto Heiskala esitteli jokin aikaan sitten tässä aikakauslehdessä Michal Mannin maailmanhistoriaa ja vallan muotoja käsitteleviä tutkimuksia (Tiede E editys 3/2015). Itse olen joskus esitellyt Historiallisessa Aikakauskirjassa (Haik 4/1996) Hans-Ulrich Wehlerin yhteiskuntahistorian käsitettä. Sen enempää Mann kuin Wehler eivät käsittääkseni ole tietoisia toistansa tutkimustoiminnasta, vaikka molempia yhdistää pyrkimys kirjoittaa yhteiskuntahistoriaa yhteiskuntatieteen teorioin ja käsittein.

Edellä kirjoitetusta ja ehkä turhan poleemisesta sävystä huolimatta pidän Eskelisen kirjaa erittäin tervetulleena ja huomionarvoisena. Ottaen huomioon sen, että se on kirjoitettu työn ohessa, voidaan lopputulosta pitää riittävän hyvänä. 